\title{
9
}

\section{THE CHANGING DYNAMICS OF BELGIAN FEDERALISM}

\author{
Is there a reversal of the \\ paradox of federalism?
}

\section{Laura Pascolo, Daan Vermassen, Min Reuchamps and Didier Caluwaerts}

\subsection{Introduction}

Ever since the 1970s, Belgium has witnessed a process of constitutional reform. This transformation of Belgium from a unitary state into a federal state was propelled by the paradox of federalism (Erk \& Anderson, 2009). After all, granting autonomy to the linguistic groups was initially considered a means of pacifying ethnolinguistic tensions, but at the same time it also legitimized and exacerbated the underlying identity conflicts. The decentralization, known in Belgium as 'defederalization' of competences, thus, seems to have increased demands for further regionalization and set in motion fundamental institutional reforms.

However, in recent years, the country seems to be experiencing a reversal of the paradox of federalism (Caluwaerts \& Reuchamps, 2020). In response to the ethnolinguistic stalemate and perceived inefficiency of Belgian politics, politicians have increasingly started advocating the 'refederalization' of certain competences. Federalism, they argue, has not delivered on its promise of efficiency and effectiveness, so the aim should be to lift competences back to the federal level. Yet very little is known so far about the positions and arguments in favor of de- or refederalization, or about the political elites' position in this debate. To map this increased attention to refederalization, this chapter aims to take stock of the positions of political elites in favor of defederalization or refederalization in Belgium. The objective is to conduct a longitudinal analysis of the argumentative logics mobilized by the political elites to justify their positions. The longitudinal analysis is carried out, on the one hand, on the electoral manifestos of the Belgian political parties and, on the other hand, on the interventions of the political elites in the written press from the end of 1990 until the last federal and regional elections of 2019 . 
The chapter is structured as follows. Section 9.2 looks at Belgium's process of federalization, more specifically as a conflict management technique from the perspective of consociational democracy. Section 9.3 includes a theoretical discussion of the paradox of federalism. Then comes the methodological part including the presentation of the two corpus and the methodological considerations. In Section 9.5, the analyses are presented, showing the main claims of the parties according to defederalization and refederalization propositions and arguments. Section 9.6 concludes and discusses the findings of the chapter.

\subsection{Consociational democracy in Belgium: from conflict to compromise and back?}

Belgium has long been considered a divided society because of its deep, coinciding cleavages. Ever since its foundation in 1830, economic, social, religious and linguistic fault lines have mutually reinforced each other. However, "[w]hat is remarkable about Belgium, is not that it is a culturally divided society - most of the countries in the contemporary world are divided into separate and distinct cultural, religious, or ethnic communities - but that its cultural communities coexist peacefully and democratically" (Lijphart, 1981, p. 1). What the Belgian case clearly shows is that deep divisions among the population need not necessarily lead to democratic disintegration. A deeply divided society can, thus, be governed in a relatively stable manner.

However, the question that has always attracted academic scrutiny is how the Belgian political system withstood the lure of centrifugalism. How come the Belgian state did not disintegrate, even though its societal structure was conflict-ridden? To understand this seemingly paradoxical finding, we need to take a closer look at the country's institutional set-up. Belgian political institutions are set up in such a way as to reduce tensions and facilitate power-sharing between the conflicting groups. In this sense, it is a prime example of what scholars of ethnic conflict call the consociational model of democracy.

The idea of consociational democracy was first developed by the Dutch academic Arend Lijphart $(1968,1981)$, who stated that “[d]ivided societies [need] a democratic regime which emphasizes consensus instead of opposition and which includes rather than excludes all the disparate components" (Lijphart, 1981, pp. 3-4). The accommodation of ethnolinguistic tensions in a conflict-ridden nation such as Belgium, thus, requires institutions that accommodate, rather than exacerbate, conflicts. They require institutions that force the elites to sit together and work out their differences. Lijphart identifies four of such power-sharing institutions.

First of all, deeply divided societies require grand coalitions. All societal groups, i.e. both majority and minority groups, should be included in executive power sharing. Consociational systems, thus, rarely settle for minimal-winning or oneparty cabinets, which exclude minorities. In Belgium, this principle is implemented by the constitutional requirement that the federal government consists 
of members of both linguistic groups, and that there is an equal number of Dutch-speaking and French-speaking cabinet members (i.e. the linguistic parity requirement). In practice, this often results in significantly oversized government coalitions consisting of five or more political parties which have to engage in consensual decision-making.

Second, the grand coalition is complemented by the principle of proportionality. Proportionality can be implemented first of all through the electoral system. Electoral proportionality allows "all groups [to] influence a decision in proportion to their numerical strength" (Steiner, 1971, p. 63; see also Lijphart, 1977, p. 39). However, proportionality has to be interpreted in a much more fundamental way: it is an impartial procedural device capable of redistributing government resources (financial means, appointments to public office...) among all societal segments (Huyse, 1970, p. 154; Steiner, 1971, p. 63). As such, it is an effective means of removing potentially explosive issues from the government agenda ensuring that "the essence of political action has shifted from strife to distribution” (Daalder, 1964, p. 24). Examples of proportionality are numerous in Belgian politics. Not only is about $60 \%$ of the seats in the federal parliament reserved for Flemish parties and 40\% for Francophone parties, but proportionality is also at the basis of Belgium's infamous waffle iron politics: every investment in Flanders has to be proportionally matched by investments in Wallonia and vice versa.

Even though their representation in grand coalitions and the application of proportionality offer minority segments a good chance of influencing policies, minority segments should also have the right to veto any decision they consider to be disadvantageous to their interests. Because the very stability of the system is at stake, the decision-making rule should approach unanimity. This gives minorities a de facto veto right, which is a far-reaching protection mechanism, that is needed to maintain the balance and avert democratic disintegration. In Belgium, this is implemented by requiring a double majority for constitutional reforms (i.e. a two-thirds majority in each assembly of the federal parliament and a simple majority within each linguistic group) and by installing a so-called alarm bell procedure. When one of the linguistic groups is convinced that a law violates its interests, that group can ring the alarm bell and suspend the parliamentary procedure. The federal government, which is composed of an equal number of French and Dutch speakers, then has to find a compromise.

The final institution aimed at reducing ethnolinguistic tensions is the granting of autonomy. When issues spark fierce debate and conflict at the national level, decision-power should ideally be delegated to the segments themselves. The aim of granting self-rule is therefore "not to abolish or weaken segmental cleavages but to recognize them explicitly and to turn the segments into constructive elements of stable democracy" (Lijphart, 1977, p. 42). Belgium has implemented this final institution by evolving from a unitary state into a federal state through six state reforms since 1970. Because the initial demands from the north and the south of the country were so different, a unique bipolar federation was created. 
Flanders primarily wanted cultural and linguistic autonomy, and protection from the francophone cultural dominance. Wallonia, on the other hand, witnessed a severe economic decline and wanted economic control. The institutional architecture of Belgian federalism was modeled after these dual demands, which led to two types of federalized entities: communities, which met Flemish demands and received cultural, linguistic and person-related competences, and regions, which would focus on economic policy (Witte \& Meynen, 2006, p. 103).

\subsection{The paradox of federalism}

These four institutional innovations foster prudent leadership and a 'spirit of accommodation' (Lijphart, 1975). They made it virtually impossible for the Flemish demographic and political majority to impose its will on the Frenchspeaking segment, and they persuaded the elites of the linguistic subgroups to sit together and resolve the matters at hand (Deschouwer, 2006, p. 902). Nevertheless, scholars have pointed out that there are inherent dangers to powersharing democracy, chief among which is the 'paradox of federalism' (Erk \& Anderson, 2009; Nordlinger, 1972). It is after all claimed that federalism removes contentious issues from the agenda, but at the same time, it sets in motion demands for more autonomy. As such, segmental autonomy, which is initially aimed at weakening centrifugal forces, actually reinforces them and could lead to separation in the long run (Caluwaerts \& Reuchamps, 2015).

One of the explanations for this paradox is that federalism strengthens regional identities instead of creating overlapping ones (Tierney, 2009, p. 246). In their early works, consociational scholars claimed that power-sharing institutions would force the elites to create overarching loyalties: by working together in the search of accommodation and compromise, the elites would over time come to trust each other, and initial segmental identities would become less salient (Jarrett, 2016). This would in turn trickle down to the general population and the initial dividing lines would become less relevant. However, rather than reduce identity salience, consociation was found to strengthen identities (Caluwaerts \& Reuchamps, 2015). On the one hand, this is because granting autonomy implicitly recognizes the validity of the underlying identity claims. Federalizing competences on culture, language and identity to the level of the communities has implicitly recognized that identity claims based on language and culture were valid. As such, further claims for autonomy and recognition were legitimized as well. On the other hand, federalism also enables the passing of legislation that promotes the development of specific regional cultures and identities (Bunce, 1999; Roeder, 1991). “[F]ederalism [thus] entrenches, perpetuates, and institutionalizes the very divisions it has designed to manage" (Simeon, 1995, p. 257).

Even though a cursory look at the Belgian state reforms in the last 50 years, with its ever-increasing levels of defederalization, seems to suggest that the paradox of federalism is unfolding, we know surprisingly little about the dynamics 
of this process. Previous studies on Belgium have not yet validated the claim that federalization led to more demands for federalization, or whether there were actually counterclaims to refederalize competences. In the next sections of this chapter, we will map the debate by identifying claims made by politicians to defederalize and refederalize competences in Belgium over time. Moreover, we will also analyze the underlying motives for de- or refederalizing competences.

\subsection{Data and methods}

\subsubsection{Two types of corpora}

To make a map of the argumentative logics supporting Belgian political parties' positions in the debate about defederalization or refederalization, this chapter performs a critical frame analysis on two types of corpora: the electoral manifestos of 13 Belgian political parties and the interventions of political decisionmakers in the French- and Dutch-speaking print media from 1999 until 2019.

Analyzing electoral manifestos is particularly relevant to assess the importance dedicated to a theme or specific issue for the political party in question. The electoral manifesto is in fact the ultimate reference document regarding the position of a political party for a given electoral campaign (Reuchamps, 2015). Furthermore, it serves several functions: it is an official document that unites all party members during the election campaign, it outlines the party's position on a number of salient issues and it is an essential source of information for voters and a guide for the actions of elected officials after the election (Biard \& Dandoy, 2018).

The electoral manifestos of Belgian political parties have been coded and analyzed, beginning from the federal election in 1999 to the last federal and regional elections in May 2019. In addition, only those parties were chosen that had obtained at least one seat in at least half of the considered elections. A total of 13 Belgian political parties ${ }^{1}$ (6 French-speaking, 6 Dutch-speaking parties and 1 unitary party) were analyzed in this way in 12 elections. In years with simultaneous (regional and federal) elections, political parties may file multiple electoral manifestos, so no fewer than 115 manifestos have been coded and analyzed in this research.

In addition to electoral manifestos, the second corpus consists of the media interventions by political decision-makers in the Belgian written press, i.e. in French and Dutch-speaking daily newspapers. ${ }^{2}$ After all, even if the manifesto is a good indicator of a party's position, the electoral campaign and competition may require adjustments on the part of political parties with regard to the different positions adopted in their electoral manifesto (Reuchamps, 2015). The use of this corpus provides a broader view of the positions of political elites through their interventions on issues and captures of the possible evolution of their positions across time. 
The collection of this second corpus is carried out over the same period (from 1999 to 2019). In addition, the data collection is carried out for the entire election year (i.e. 1 January to 31 December), so that it includes the pre-campaign period, the election campaign, as well as the formation of coalitions and the underlying negotiations during the constitution of the executives. The selection resulted in 278 press articles that contained directly quoted interventions by political elites and were subsequently coded. Opinion pieces, political columns and interventions and analyses by experts in the broadest sense were excluded.

\subsubsection{Critical frame analysis}

To identify the arguments surrounding the defederalization or refederalization debate in Belgium, we conducted a critical frame analysis (Verloo, 2005). Critical frame analyses allow implicit or explicit interpretations of the political problem to emerge by highlighting how political actors think about the problem and present solutions (Meier, 2008). Indeed, this approach makes it possible to draw up an in-depth study of the diagnostic and prognostic dimensions by insisting on the implicit or explicit representations of the actors, causes, consequences and actions to be undertaken.

For the purposes of this chapter, electoral proposals and media interventions have been coded according to a two-fold scheme. On the one hand, we have coded the diagnostic frames that seek to highlight the diagnosis of the problem (what is the problem?), its justification (why is it a problem?), causality (what caused the problem?) and attribution (who is responsible for the problem?). On the other hand, we also coded the prognostic frames concerning the prognosis (what is defined as the solution?), the actions (how can we solve the problem?) but also the different objectives, values and highlighted norms. These two types of frames make it possible, on the one hand, to look at how political parties and their elites define de- and refederalization and, on the other hand, to understand why they support the deand refederalization of competences and responsibilities. Finally, by understanding the diagnostic and prognostic frames, it is possible to highlight the argumentative logics mobilized by political elites to justify such transfers of competences (toward a centrifugal of defederalization or centripetal of refederalization trajectory).

\subsection{Findings}

\subsubsection{The evolution of the debate}

Before presenting and elaborating on the different frames and arguments used by political elites to justify their positions for or against de- and refederalization, it is necessary to determine the extent to which these two issues have been actively discussed through the manifestos of political parties and in the interventions of their representatives in the print media. Figure 9.1 shows the evolution of the debate on the distribution of competences over time. The general trends 


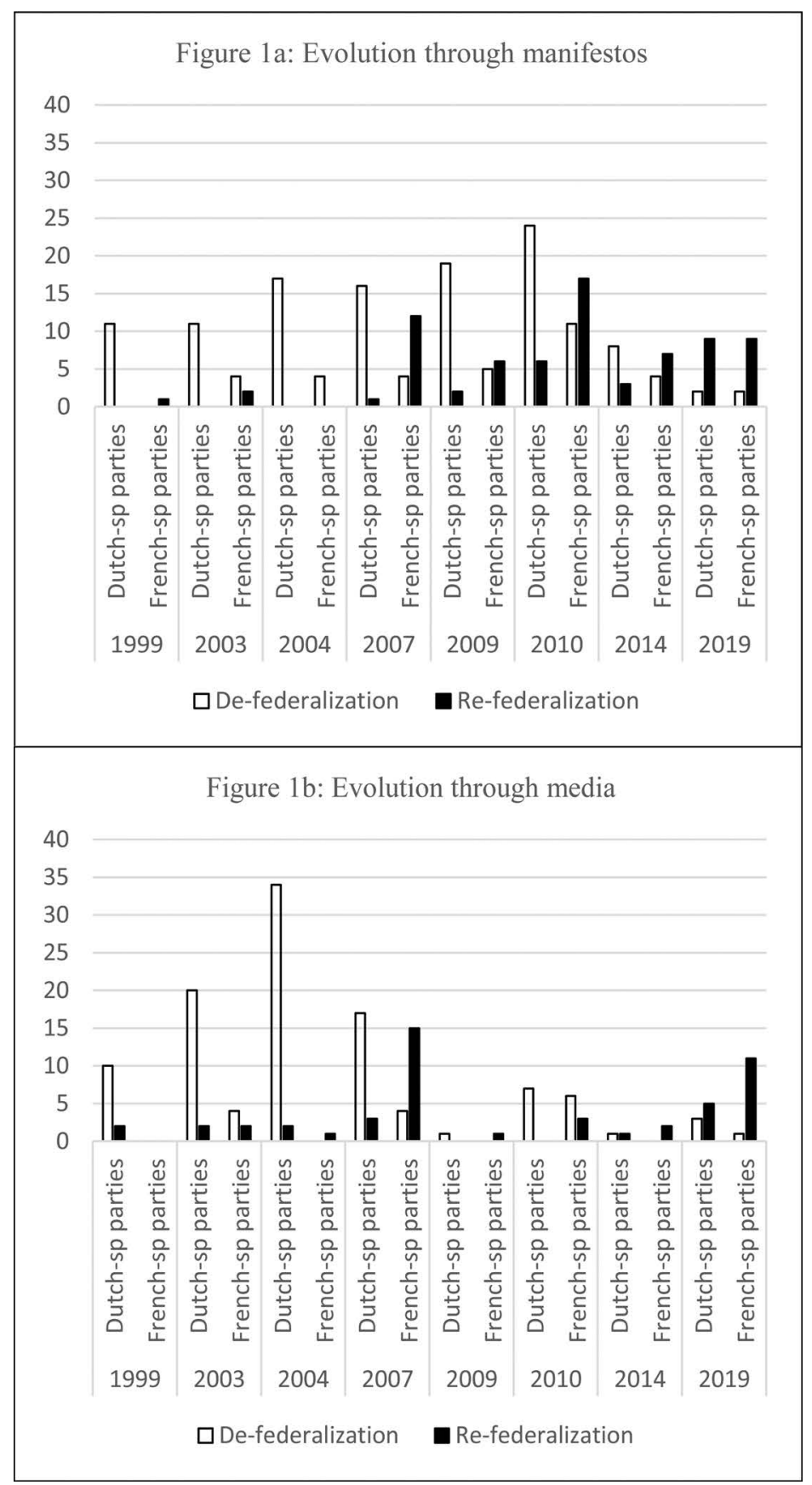

FIGURE 9.1 Evolution of the debate on de- and refederalization over time for Dutch-speaking parties and French-speaking parties (claims in absolute occurrences) 
show that demands for defederalization of competences are more numerous in the earlier elections. Moreover, a peak of these demands is observed in the 2010 elections and in the first phase of the 6th and currently last reform of the state in 2012-2014. However, in the last two federal and regional elections (2014 and 2019), there was a decrease in these claims for defederalization. The constitutional reforms agreed upon during the last state reform seem to have satisfied some of parties' appetite for further decentralization of competences.

However, although previous state reforms have historically and systematically generated centrifugal transfers of competences, we also observe that demands for refederalization have increased since the 2007 federal elections. However, it is during the regional and federal elections of 2010 and 2019 but also after the last state reform finished in 2014, that the demands for refederalization of competences were the most important.

A number of additional observations should also be highlighted. First of all, even if the demands for refederalization seemed to be more important in the last two election years, they are not shared in the same way by the political parties in the north and south of the country. Indeed, the Dutch-speaking political parties have almost systematically made more demands for defederalization both in their electoral manifestos and in the interventions of the political elites. However, in the federal and regional elections of 2019, demands for the refederalization of competences have become more prominent in the speeches of these political elites (see Table 9.1). In addition, the demands for the defederalization of competences are, among others, mainly and predominantly driven by Dutch-speaking parties, including the N-VA and the VB. In contrast, representatives of the so-called traditional political parties such as the liberal Open VLD, Christian-democratic CD\&V and socialist SP.A have formulated multiple demands with a high relative weight through their interventions in the media. However, media analyses show that representatives of the three traditional Dutch-speaking political parties (CD\&V, Open VLD, SP.A) also put forward positions and demands for the refederalization of competences and responsibilities. The only Dutch-speaking party that has included demands of refederalization in the interventions of its political elites in print media but also in its electoral manifestos is the green party, Groen.

Demands for defederalization have also been formulated on the other side of the language border. The traditional French-speaking parties (cdH, MR, PS) formulate them both in their electoral manifestos and in their media interventions. However, starting with the 2007 federal elections, French-speaking parties almost systematically made more demands for refederalization than defederalization. The two parties with a large share of claims referring to the refederalization of competences in their electoral manifestos are, on the one hand, the Frenchspeaking liberal party, MR and, on the other hand, the only Belgian unitary party, the far-left party PTB/PVDA.

Before closing this section presenting the evolution of the debate, it is interesting to highlight a consideration about an intermediate position, a balance between defederalization and refederalization observed during the analysis of 
TABLE 9.1 Claims on de-/refederalization by political parties (in absolute and relative occurrences)

\begin{tabular}{|c|c|c|c|c|c|}
\hline & & \multicolumn{2}{|c|}{ Defederalization } & \multicolumn{2}{|c|}{ Refederalization } \\
\hline & & Manifestos & Media & Manifestos & Media \\
\hline \multirow[t]{2}{*}{ Christian-democrat } & $\mathrm{cdH}$ & $3.40 \%(N=5)$ & $0.97 \%(N=1)$ & $7.14 \%(N=4)$ & $10.64 \%(N=5)$ \\
\hline & $\mathrm{CD} \& \mathrm{~V}$ & $6.12 \%(N=9)$ & $16.50 \%(N=17)$ & $0 \%(N=0)$ & $6.38 \%(N=3)$ \\
\hline \multirow[t]{2}{*}{ Ecologist } & Groen & $3.40 \%(N=5)$ & $0.97 \%(N=1)$ & $12.50 \%(N=7)$ & $4.26 \%(N=2)$ \\
\hline & Ecolo & $5.44 \%(N=8)$ & $0 \%(N=0)$ & $14.29 \%(N=8)$ & $8.51 \%(N=4)$ \\
\hline \multirow[t]{2}{*}{ Liberal } & Open VLD & $8.84 \%(N=13)$ & $20.39 \%(N=21)$ & $0 \%(N=0)$ & $10.64 \%(N=5)$ \\
\hline & MR & $3.40 \%(N=5)$ & $5.83 \%(N=6)$ & $23.21 \%(N=13)$ & $17.02 \%(N=8)$ \\
\hline \multirow[t]{2}{*}{ Regionalist } & $\mathrm{N}-\mathrm{VA}$ & $23.81 \%(N=35)$ & $23.30 \%(N=24)$ & $0 \%(N=0)$ & $0 \%(N=0)$ \\
\hline & FDF/Défi & $2.04 \%(N=3)$ & $0 \%(N=0)$ & $5.36 \%(N=3)$ & $0 \%(N=0)$ \\
\hline \multirow[t]{3}{*}{ Radical right } & $\mathrm{VB}$ & $28.57 \%(N=42)$ & $1.94 \%(N=2)$ & $0 \%(N=0)$ & $0 \%(N=0)$ \\
\hline & $\mathrm{PP}$ & $4.08 \%(N=6)$ & $0 \%(N=0)$ & $7.14 \%(N=4)$ & $0 \%(N=0)$ \\
\hline & LDD & $1.36 \%(N=2)$ & $0 \%(N=0)$ & $0 \%(N=0)$ & $0 \%(N=0)$ \\
\hline \multirow[t]{2}{*}{ Socialist } & PS & $7.48 \%(N=11)$ & $7.77 \%(N=8)$ & $8.93 \%(N=5)$ & $31.25 \%(N=15)$ \\
\hline & SP.A & $2.04 \%(N=3)$ & $23.30 \%(N=24)$ & $0 \%(N=0)$ & $6.38 \%(N=3)$ \\
\hline Radical left & PTB/PVDA & $0 \%(N=0)$ & $0 \%(N=0)$ & $21.43 \%(N=12)$ & $4.26 \%(N=2)$ \\
\hline
\end{tabular}


media interventions for the last federal and regional elections. During the 2019 election year, and particularly in the debates and discussions concerning a possible 7 th reform of the state, intermediate positions on the trajectory to be taken by the transfer of competences and responsibilities emerged.

The political elites in this 'in-between' position stressed that a future reform of the State should encompass both a defederalization of competences and a refederalization of particular competences. These political elites highlight a trajectory not yet planned in previous state reforms, which would consist of a mixed trajectory between a centrifugal and a centripetal approach to the transfer of competences. These 'intermediate' positions were advocated by various political representatives from political parties in both the north and the south of the country. However, such a hybrid trajectory is far from being shared by all political elites and also tends to reflect rather individual positions of the elites within their political parties. However, this intermediate position is mentioned in the latest government agreement (30 September 2020), which indicates in particular the bases for a possible 7 th reform of the State. The government agreement seems to address a new way of distributing competences and powers, presenting, on the one hand, an increase in the competences and autonomy of the federated entities and, on the other hand, a strengthening of the powers of the Federal Authority.

\subsubsection{Critical frame analysis on de-/refederalization}

Now that we have mapped the debate on de- and refederalization over the last 20 years, we should identify the argumentative logics underlying the debate. Political elites are after all actively engaging in defining and constructing problems related to management and competences transfer according to different diagnostic frames. Indeed, to justify their claims for or against re/defederalization, they highlight various dysfunctions underlying the practices and modalities at the heart of the Belgian federal political system which are both perceived as causes and consequences of the federal dynamics that have shaped the Belgian federation. Furthermore, the different frames mobilized by the political elites to justify centrifugal or centripetal responses have highlighted different argumentative logics adopted by the political elites in their demands in favor of or against the re-/defederalization of competences. The different argumentative logics can be divided into two main types of argument categories: on the one hand, identity-based arguments highlighting the differences between communities in terms of language, culture and politics and, on the other hand, functional, efficiency-based arguments which focus on considerations of economic efficiency, homogeneity of competences or cost reduction (see Table 9.2).

Two diagnostic frames are used by proponents of defederalization, as well as by proponents of refederalization, although the arguments differ. The first frame concerns the lack of coherence which refers to the heterogeneity, fragmentation and dispersion of competences. Indeed, policy areas have been devolved to different political entities, but powers and responsibilities have not been devolved 
TABLE 9.2 The main diagnostic frames and related arguments

\begin{tabular}{|c|c|c|c|c|c|}
\hline \multicolumn{3}{|c|}{ Defederalization } & \multicolumn{3}{|c|}{ Refederalization } \\
\hline \multirow{2}{*}{$\begin{array}{l}\text { Diagnostic } \\
\text { frames }\end{array}$} & \multicolumn{2}{|c|}{ Arguments } & \multirow[b]{2}{*}{ Diagnostic frames } & \multicolumn{2}{|c|}{ Arguments } \\
\hline & Efficiency & Identity & & Efficiency & Identity \\
\hline $\begin{array}{l}\text { Lack of } \\
\text { coherence }\end{array}$ & $\begin{array}{l}\text { Coherence } \\
\text { Homogeneity } \\
\text { Economy }\end{array}$ & & $\begin{array}{l}\text { Lack of } \\
\text { coherence }\end{array}$ & $\begin{array}{l}\text { Coherence } \\
\text { Homogeneity } \\
\text { Economy }\end{array}$ & \\
\hline $\begin{array}{l}\text { The } \\
\text { institutional } \\
\text { architecture }\end{array}$ & $\begin{array}{l}\text { Democracy } \\
\text { Modernity } \\
\text { Equality }\end{array}$ & & $\begin{array}{l}\text { The institutional } \\
\text { architecture }\end{array}$ & $\begin{array}{l}\text { Responsibility } \\
\text { Modernity } \\
\text { Simplification }\end{array}$ & $\begin{array}{l}\text { Common } \\
\text { history/ } \\
\text { culture }\end{array}$ \\
\hline $\begin{array}{l}\text { Lack of } \\
\text { autonomy }\end{array}$ & $\begin{array}{l}\text { Subsidiarity } \\
\text { Coordination }\end{array}$ & $\begin{array}{l}\text { Common } \\
\text { history, } \\
\text { language, } \\
\text { culture }\end{array}$ & $\begin{array}{l}\text { Lack of } \\
\text { coordination }\end{array}$ & $\begin{array}{l}\text { Cohesion } \\
\text { Coordination } \\
\text { Unity }\end{array}$ & \\
\hline $\begin{array}{l}\text { Flemish- } \\
\text { Walloon } \\
\text { differences }\end{array}$ & Economy & $\begin{array}{l}\text { Political } \\
\text { differences } \\
\text { Diversity }\end{array}$ & $\begin{array}{l}\text { Partisans for } \\
\text { defederalization }\end{array}$ & Solidarity & \\
\hline $\begin{array}{l}\text { The power } \\
\text { and } \\
\text { competences } \\
\text { of the federal } \\
\text { level }\end{array}$ & $\begin{array}{l}\text { Expertise } \\
\text { Subsidiarity } \\
\text { Transparency }\end{array}$ & $\begin{array}{l}\text { Share power } \\
\text { Division }\end{array}$ & $\begin{array}{l}\text { The } \\
\text { management of } \\
\text { the political } \\
\text { domain }\end{array}$ & $\begin{array}{l}\text { Transparency } \\
\text { Uniformity }\end{array}$ & \\
\hline
\end{tabular}

to the same extent. As a result, they point out a lack of coherence in the management of a particular policy area due to a nonhomogeneous distribution of competences from the same policy area. This lack of coherence is illustrated in different policy areas subject to de-/refederalization. In fact, in the field of public health, different parts of competences and responsibilities are dispersed between the different levels of government. Moreover, the solutions proposed to resolve of this lack of coherence can go in completely opposite ways according to political elites. Some claim that coherence can be solved by further devolving competences; others claim that the solution lies in refederalization. Nevertheless, the centrifugal or centripetal response addressed to this diagnostic frame is justified by the political elites through the use of argumentative logics of efficiency, highlighting economic prosperity, homogeneity and coherence in the transfer of competences. The political elites favoring the refederalization of competences have largely mobilized this diagnostic frame in their manifestos.

The institutional architecture is the second frame shared by the political parties, which propose different trajectories concerning the distribution of competences. The main causes and origins of this complex institutional architecture stem from the different institutional reforms that have successively taken place in the course of arrangements and negotiations. The institutional mechanisms, which is considered complex, are highlighted by the political elites to underline and justify a solution whose objectives aim to overcome various institutional dysfunctions. In reality, the dysfunctions highlighted by the political elites differ according to the prognostic 
frameworks, between the two trajectories advocated by the political elites. The advocates of a defederalization of competences emphasize the difficulties and dysfunctions linked to asymmetrical principles and instruments of so-called cooperative federalism such as solidarity mechanisms, veto rights inherent in the principles of consociational democracy or other measures requiring coordination at the level of the federal authority. These political elites justify the resolution of these dysfunctions through the defederalization by highlighting arguments such as the strengthening of the equality of the constituent entities but also of the democracy and the modernity of Belgian institutional system. This diagnostic frame underlines the dysfunction of institutional instruments and mechanisms and has been strongly mobilized by political elites in favor of defederalization in their manifestos.

Meanwhile, the political elites advocating refederalization argue that the electoral system underlying this institutional architecture does not allow the election of a part of the political representatives over the entire political territory via, in particular, a federal constituency. In fact, some political elites mobilize argumentative logics of identity but also of efficiency that underline a common historical and cultural identity which, due to the divided and complex institutional architecture, seems to be broken down. They also highlight the fact that within this federal system, there is a multiplication of levels of power that generates numerous costs and dysfunctions of governance while exacerbating a competitive federalism and a competition between levels of power. They therefore propose to resolve various dysfunctions through refederalization of competences by emphasizing democratic but also functional considerations of simplification and modernization. Moreover, this frame seems to be close with the frame 'lack of coherence'. However, they differ in the sense that the institutional architecture frame rather emphasizes the institutional processes and mechanisms while the lack of coherence frame points to fragmentation in the distribution of competences.

However, if we look at the other diagnostic frames that were used by the political elite, the frames used by the proponents of defederalization and the advocates of refederalization are diametrically opposed. On the one hand, the political elites who stress the lack of coordination emphasize the concern to obtain a uniform policy to the detriment, for example, of Belgium's representation on the international scene. On the other hand, this need for coordination is also stressed in relation to more cross-cutting issues which advocate a unity of command to manage and coordinate policies in these areas of competence. This diagnostic frame that highlights the lack of coordination in the management of common policies is particularly emphasized by the political elites who favor centripetal solutions. On the other hand, the political elites arguing for a defederalization of competences do not favor policy coordination but rather express a desire for greater autonomy in the representation of their interests at the level of international institutions and also in the management of more crosscutting issues. These political elites advocating a centrifugal trajectory juggle with different argumentative logics by coupling and underlining their justifications with identity-based arguments that protect their own interests and 
identity, but also with arguments of efficiency highlighting considerations of subsidiarity and coordination of their specific competences.

Furthermore, by considering these opposing diagnostic frames, political elites who seek a centrifugal or centripetal response construct and attribute the underlying difficulties to their justifications around frames that can be understood as frames of responsibility. That is between, on the one hand, the intrinsic differences in ideological, political or even cultural visions between the two communities and, on the other hand, the centrifugal pressures and demands fed by political elites with ever-increasing demands for the defederalization of competences. Indeed, the problems are sometimes construed around the idea that there are fundamental differences in points of view and visions between the two communities. According to the political elites who mobilize this frame, political, economic and cultural differences do not allow for effective cooperation and work on common policies. In contrast, the political elites supporting the refederalization attribute responsibility for competence management problems to the protagonists who have shaped federal dynamics and previous state reforms in a centrifugal movement of defederalization of responsibilities and competences. They propose the refederalization of competences by supporting, among other things, considerations of solidarity between different communities.

Finally, the last two frames underline the difficulties and problems concerning the management of particular competences and responsibilities at the level of power where they reside. On the one hand, supporters of defederalization argue that many competences and powers are still exercised by the federal authority and that, as a result, federalism is not yet fully achieved. This frame concerns the main diagnostic frame underlying the distribution of competences and powers mobilized by political elites in their media interventions to justify a defederalization of competences. These political elites mobilize argumentative logics of efficiency, emphasizing that the substate levels are more qualified in terms of expertise and transparency but are also closer to the citizens to manage the competences still devolved to the federal authority. On the other hand, supporters of refederalization point out that certain competences, responsibilities that were devolved during previous state reforms, do not function properly at the level of power where they are exercised and therefore justify a refederalization of these competences. Moreover, the political elites who point out these dysfunctions justify that a transfer of competences and responsibilities following a centripetal trajectory will allow for simplification but also for greater transparency and uniformity in the management of these institutions.

\subsection{Conclusion}

In recent years, the dynamics of Belgian federalism seem to have changed and highlight a reversal of the paradox of federalism. Through this chapter, the objective of this longitudinal analysis of the critical frame was to draw up and explore the positions and underlying argumentative logics mobilized by the political elites 
to justify their centripetal or centrifugal positions regarding the distribution of powers and competences. The critical frame analysis has made it possible to highlight various similar but also divergent diagnostic frames mobilized by political elites to correct dysfunctions in the distribution of powers and responsibilities along diametrically opposed trajectories (de-/refederalization). The political elites particularly mobilize argumentative logics of efficiency to justify their positions.

Moreover, this research highlighted the fact that the Belgian federal dynamics are being transformed. Indeed, although all six institutional reforms have systematically been driven by a centrifugal dynamic, the demands for defederalization still seem to be important, particularly with regard to the Dutch-speaking political parties. However, since the last federal and regional elections in 2019, centripetal demands for refederalization of competences have become more prominent. These centripetal demands are particularly highlighted in the interventions in the written press of representatives of various political parties in the north of the country. However, the French-speaking parties have given greater support to these refederalization demands at least since the 2007 federal elections. In addition, during the 2019 election year, intermediate positions proposing a combination of the centrifugal and centripetal approaches appeared in the discourse of some political representatives from the north and south of the country. However, it is important to point out that these demands for refederalization or a hybrid trajectory are not shared by all political elites. However, the increasingly widespread demands by French- and Dutch-speaking political parties and elites for the refederalization of competences and the advent of this hybrid trajectory seem to indicate that a reversal of the paradox of federalism could prove probable and take shape in a possible future 7 th reform of the state, the agreement sealing the current legislature of which seems to have laid the foundations for future discussions and talks.

\section{Notes}

1 The French Christian-democrats $(\mathrm{cdH})$, the Dutch Christian-democrats $(\mathrm{CD} \& \mathrm{~V})$, the French ecologist party (ECOLO), the French regionalist party (FDF/Défi), the Dutch ecologist party (Groen), the Dutch radical right party (LDD), the French liberal party (MR), the Dutch nationalist party (N-VA), the Dutch liberal party (Open VLD), the French radical right party (PP), the French socialist party (PS), the single unitary and radical left party (PTB/PVDA), the Dutch socialist party (sp.a), and the Dutch radical right party $(\mathrm{VB})$.

2 The main dailies selected for this research are for the Dutch-speaking press: De Morgen, De Standaard, De Tijd, Het Gazet van Anterwpen, Het Belang van Limburg, Het Nieuwsblad, Het Laaste Nieuws. For the French-speaking press: L'Avenir, L'Echo, La Dernière Heure, La Libre Belgique, Le Soir, Sud presse.

\section{References}

Biard, B., \& Dandoy, R. (2018). Les préférences démocratiques au sein des partis populistes en Belgique. In B. Biard (ed.), L'Etat face à ses transformations. Louvain-La-Neuve: AcademiaL'Harmattan, pp. 231-257. 
Bunce,V. (1999). Subversive Institutions: The Design and the Destruction of Socialism and the State. New York, NY: Cambridge University Press.

Caluwaerts, D., \& Reuchamps, M. (2015). Combining Federalism with Consociationalism: Is Belgian Consociational Federalism Digging its Own Grave? Ethnopolitics 14(3): 277-295.

Caluwaerts, D., \& Reuchamps, M. (2020). Still Consociational? Belgian Democracy, 50 Years after 'The Politics of Accommodation'. Politics of the Low Countries 2(1): 28-50.

Daalder, H. (1964). Leiding en lijdelijkheid in de Nederlandse politiek. Assen:Van Gorcum.

Deschouwer, K. (2006). And the Peace Goes on? Consociational Democracy and Belgian Politics in the 21st Century. West European Politics 29(5): 895-911.

Erk, J., \& Anderson, L. (2009). The Paradox of Federalism: Does Self-Rule Accommodate or Exacerbate Ethnic Divisions? Regional \& Federal Studies 19(2): 191-202.

Huyse, L. (1970). Passiviteit, Pacificatie en Verzuiling in de Belgische Politiek. Een Sociologische Studie. Antwerpen: Standaard Wetenschappelijke Uitgeverij.

Jarrett, H. (2016). Consociationalism and Identity in Ethnically Divided Societies: Northern Ireland and Malaysia. Studies in Ethnicity and Nationalism 16(3): 401-415.

Lijphart, A. (1968). Verzuiling, Pacificatie en Kentering in de Nederlandse Politiek. Amsterdam: J. H. De Bussy.

Lijphart, A. (1975). The Politics of Accommodation: Pluralism and Democracy in the Netherlands. Berkeley, CA: University of California Press.

Lijphart, A. (1977). Democracy in Plural Societies. A Comparative Exploration. New Haven, CT: Yale University Press.

Lijphart, A. (1981). Introduction: The Belgian Example of Cultural Coexistence in Comparative Perspective. In A. Lijphart (ed.), Conflict and Coexistence in Belgium: The Dynamics of a Culturally Divided Society. Berkeley, CA: Institute of International Studies.

Meier, P. (2008). Critical Frame Analysis of EU Gender Equality Policies: New Perspectives on the Substantive Representation of Women. Representation 44(2): 155-167.

Nordlinger, E. A. (1972). Conflict Regulation in Divided Societies. Cambridge, MA: Harvard University Center for International Affairs.

Reuchamps, M. (ed.) (2015). Minority Nations in Multinational Federations: A Comparative Study of Quebec and Wallonia. London: Routledge.

Roeder, P. G. (1991). Soviet Federalism and Ethnic Mobilization. World Politics 43(2): 196-232.

Simeon, R. (1995). Canada and the US: Lessons from the North American Experience. In K. Knop, S. Ostry, R. Simeon, K. Swinton (eds.), Rethinking Federalism: Citizens, Markets, and Governments in a Changing World.Vancouver: UBC Press, pp. 250-272.

Steiner, J. (1971). The Principles of Majority and Proportionality. British Journal of Political Science 1(1): 63-70.

Tierney, S. (2009). Federalism in a Unitary State: a Paradox too Far? Regional \& Federal Studies 19(2): 237-253.

Verloo, M. (2005). Mainstreaming Gender Equality in Europe: A Critical Frame Analysis Approach. The Greek Review of Social Research 117(B): 11-34.

Witte, E., \& Meynen, A. (2006). De geschiedenis van België na 1945. Antwerpen: Standaard Uitgeverij. 